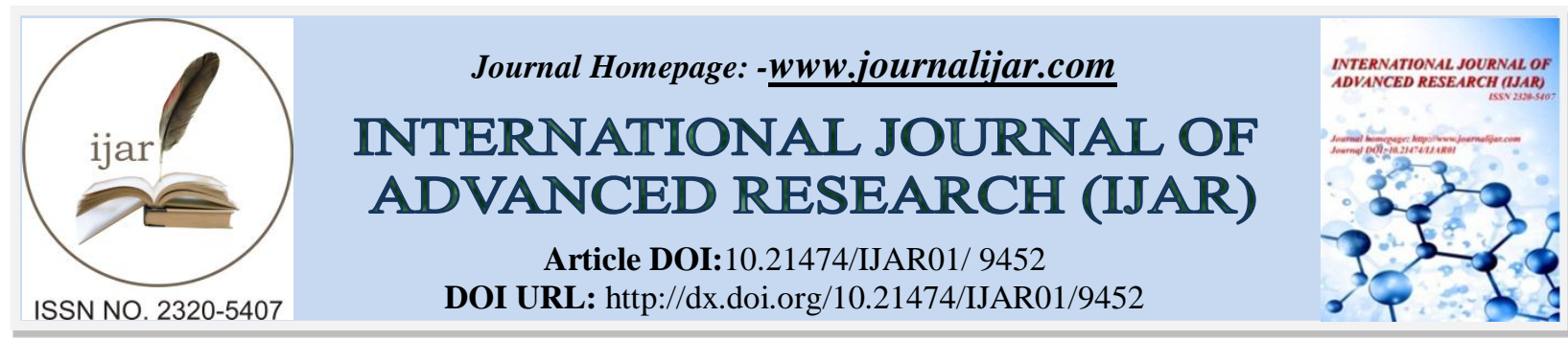

RESEARCH ARTICLE

\title{
ESSENTIAL HYPERTENSION: WHAT AYURVEDA CAN OFFER.
}

\author{
Himani $^{1}$, Alok Kumar Srivastava ${ }^{2}$, Parul Sharma ${ }^{3}$ and Krishna Kumar Sharma ${ }^{4}$. \\ 1. MD Scholar, Department of Panchakarma, Rishikul Campus, UAU, Haridwar. \\ 2. HOD And Professor, Department of Panchakarma, Main Campus, UAU, Harrawala. \\ 3. Assistent Professor, Department of Panchakarma, Rishikul Campus, UAU, Haridwar. \\ 4. HOD And Professor, Department of Panchakarma, Rishikul Campus, UAU, Haridwar.
}

\section{Manuscript Info}

\section{Manuscript History}

Received: 24 May 2019

Final Accepted: 26 June 2019

Published: July 2019

\section{Key words:-}

Essential hypertension, cardiovascular health, Panchakarma, Herbal drugs.

\begin{abstract}
Hypertension (HTN) exerts a substantial public health burden on cardiovascular health status and healthcare systems in India. HTN is directly responsible for $57 \%$ of all stroke deaths and $24 \%$ of all coronary heart disease (CHD) deaths in India. Among the patients taking allopathic treatment, only about $25.6 \%$ of treated patients had their BP under control. This demands a treatment protocol which can give safer and effective results. Ayurveda in the form of Panchakarma, herbal and herbo-mineral drugs can offer a helping hand.
\end{abstract}

Copy Right, IJAR, 2019,. All rights reserved.

\section{Introduction:-}

Human life has been considered as a valuable opportunity to achieve the prime goal of life viz. Dharma, Artha, Kama \& Moksha ${ }^{[1]}$. To achieve this, one needs a Healthy and Calm life. But in the race of money and so called development, man has left his prime goal behind. Therefore today's Metaphysical Society is facing unsteady, weakened, hard \& everyday changing lifestyle. The Stressful and hurried life style of today affects one's mind and homeostasis of body by several psychosomatic mechanisms causing many psychosomatic disorders and essential hypertension is one of those diseases. Hypertension is sustained high blood pressure; sometimes also called arterial hypertension, is a chronic medical condition in which the blood pressure in arteries is elevated ${ }^{[2]}$. When the cause is not known, it is called idiopathic or essential hypertension ${ }^{[3]}$.It is also called as a silent or hidden killer because most of the sufferers $(85 \%)$ are asymptomatic ${ }^{[2]}$. This feature of hypertension is responsible for a huge number of cases remaining undiagnosed. Recent studies from India have shown the prevalence of HTN to be $25 \%$ in urban and $10 \%$ in rural people in India ${ }^{[4]-[6]}$.

In Ayurveda classics, there is no direct correlation mentioned for hypertension. But it is said in Ayurveda texts"In case of an unknown disease, the physician should try to understand the nature of the disease through dosha, the site of manifestation, etiological factors and then should initiate the treatment" ${ }^{\text {[7] }}$.

\section{Material and methods:-}

The pathogenesis of hypertension takes place at both physical and psychic level one at a time or simultaneously depending upon the Dosha-Dushya Sammurchhana. Agnidushti results in Ama formation and subsequent Dhatudushti (Rasa and Rakta). This leads to Kha-Vaigunya i.e. obstructive pathology in channels. The Ama production results into Strotorodha (obstruction) and thus partially blocks the normal Rasa- Rakta circulation which 
further vitiates Vyana Vayu. This obstructed Vyana Vayu leads to forcible blood flow in the blood vessels causing increased resistance, hereby increasing blood pressure ${ }^{[8] \text {. }}$

Ayurveda has three principles of management for any disease namely:

1. Nidana Parivarjana

2. Shodhana

3. Shamana

\section{Nidan parivarjan ${ }^{[9]}$}

It means avoiding the causative and risk factors. In case of essential hypertension patient should follow the following pathya and apathya.

\begin{tabular}{|l|l|}
\hline 1) PATHYA(DO'S) & 2) APATHYA(DONT'S) \\
\hline $\begin{array}{l}\text { VIHAR- } \\
\text { Regular blood pressure check-up }\end{array}$ & $\begin{array}{l}\text { VIHAR- } \\
\text { Practice of day sleeping and awakening at night. }\end{array}$ \\
$\begin{array}{l}\text { Lifestyle modifications like timely intake of } \\
\text { balanced diet, regular physical exercise, daily brisk } \\
\text { walking for half an hour }\end{array}$ & \\
Weight reduction & \\
Timely sleeping and awakening. \\
$\begin{array}{l}\text { Regular practice of Yoga, Meditation etc. under the } \\
\text { supervision of Yoga expert }\end{array}$
\end{tabular}

\section{Shodhana}

Shodhana means purification of the body by eliminating morbid doshas and dushyas from body through panchakarma hence breaking the samprapti of disease.Through various researches done on essential hypertension, following shodhana therapies can be done:

1. Virechan

2. Basti- ksheer basti, lekhan basti,etc

3. Nasya

4. Shirodhara- takradhara, jaladhara, tailadhara, etc

5. Raktamokshan- siravedh etc

\section{Shaman -}

The principle of shaman therapy is to normalize and maintain the equilibrium of all the doshas. The following drugs (single/compound formulation) are commonly used for prevention and control of Hypertension (to be taken under Ayurvedic medical supervision):

\section{Single drugs-}

Amalaki, Jyotishmati, Chhangal Jadi, Rudraksha, Haridra, Japapushpam , Jatamamsi, Punarnava, Bhringraj, Sadabahar, Sarpagandha, Shankhapushpi, Shigru, Tagar, Vacha ${ }^{[10]}$. 


\section{Compound drugs-}

Arjun Ksheerpaka, Brahma Rasayan, Chandralekha Rasam, Chyavana Prasha, Guduchi Rasayanam, Jatamamsi Kwath, Jatamamsyadi Yoga, Madhuparnyadi Yogam, Mahavat Vidhwansak Rasa, Mangalyakusuma Mansyadi Yoga, Medhya Rasayanam, Medhya Vati, Nirvishi Sindoora Kalpa, Prasadi Vati, Prasadini Vati, Rasagandhati Vati, Rasa Sindoora, Sarpagandha Ghan Vati, Shodashang Kashaya, Vacha-Mansyadi Yoga ${ }^{[10]}$.

\section{Non pharmacological measures-}

Pranayam, yoga therapy, shavasan

\section{On the basis of form of medicine:}

1. Kashayam (Decoction) - Jatamansi Hima, Dashmool Kwath, Arjun Kwath, Punarnava Kwath, Mahamanjistha Kwatha

2. Choorna (Powder) - Choorna Of Sarpaghandha, Arjuna And Gokshura, Ashawaghandha Choorna, Tagar

3. Bhasma (Rasa preparation) - Mukta Pisti, Jaharmohra Pisti, Mukta Shukti.

4. Vati (Tablet) - Sarpagandha Ghana Vati, Brahmi Vati ${ }^{[2]}$.

Here is the list of plants that have antihypertensive properties ${ }^{[1]}$ :

\begin{tabular}{|c|c|c|c|}
\hline Drug & Botanical name and family & Part Used & Chemical Constituents \\
\hline Sarpagandha & $\begin{array}{l}\text { Rauvolfia } \\
\text { serpentine; Apocynaceae }\end{array}$ & Root & $\begin{array}{l}\text { Ajmaline, Rescinnamine, Serpentinine, } \\
\text { Sarpagine, Deserpidine, And Chandrine }\end{array}$ \\
\hline Lashun & Alium sativum; Liliacae & Bulbils & $\begin{array}{l}\text { Sulfur Containing Compounds Alliin, } \\
\text { Ajoene, Diallylsulfide, Dithiin, } \\
\text { Sallylcysteine }\end{array}$ \\
\hline Aadrak & $\begin{array}{l}\text { Gingiber officinalis; } \\
\text { Zingiberaceae }\end{array}$ & Rhizomes & $\begin{array}{l}\text { Volatile Oil ; 3sesquiterpines:- Bisaboline, } \\
\text { Zingiberene And Zingiberol }\end{array}$ \\
\hline Jalbrahmi & Centella ascitica; Aplaceae & $\begin{array}{l}\text { Whole } \\
\text { Plant }\end{array}$ & $\begin{array}{l}\text { Pentacyclic Triterpenes } \\
\text { Derivativesmadecassosides And } \\
\text { Asiaticosides. }\end{array}$ \\
\hline Arjun & $\begin{array}{l}\text { Termenalia arjuna; } \\
\text { Combretaceae }\end{array}$ & Bark & $\begin{array}{l}\text { Tannins, Triterpenoid Saponins, } \\
\text { Flavonoids, Gallic Acid, Ellagic Acid, } \\
\text { Opcs, Phytosterols, Calcium, Magnesium, } \\
\text { Zinc, And Coppe }\end{array}$ \\
\hline Black cumin seed & Nigella sativa; Ranunculaceae & Seed & $\begin{array}{l}\text { Thymoquinone, Dithymoquinone, } \\
\text { Thymohydroquinone, Thymol, Carvacrol, } \\
\text { Tanethole And 4-Terpineol. H }\end{array}$ \\
\hline Ashwagandha & Withania somnifera; Solanaceae. & $\begin{array}{l}\text { Whole } \\
\text { Plant }\end{array}$ & $\begin{array}{l}\text { Alkaloids Including Withanine, } \\
\text { Withananine, Withananinine, } \\
\text { Pseudowithanine, Somnine, Somniferine, } \\
\text { Somniferinine. The Leaves Of Indian } \\
\text { Chemotype Contain Withanolides, } \\
\text { Including Withaferin }\end{array}$ \\
\hline Bhringraj & $\begin{array}{l}\text { Eclipta prostrata /Eclipta alba ; } \\
\text { Asteraceae }\end{array}$ & Leaves & $\begin{array}{l}\text { Wedelolactone And Dimethyl } \\
\text { Wedelolactone, Ascorbic Acid. Alkaloid, } \\
\text { Ecliptine. Thiophene Derivatives Mono-, } \\
\text { Di- And Trithiophene Acetylenes Together } \\
\text { With A-Terthenyl In ß-Sitosterol. The } \\
\text { Roots Are Very Rich In Thiophene } \\
\text { Acetylenes. Active Constituent, Culumbin, } \\
\text { Exhibited Remarkable Antihypertensive } \\
\text { Activity }\end{array}$ \\
\hline Punarnava & $\begin{array}{l}\text { Boerhavia diffusa; } \\
\text { Nyctaginaceae }\end{array}$ & $\begin{array}{l}\text { Whole } \\
\text { Plant }\end{array}$ & $\begin{array}{l}\text { Punarnava Contains B-Sitosterol, A-2- } \\
\text { Sitosterol, Palmitic Acid, Ester Of } \\
\text { Bsitosterol, Tetracosanoic, Hexacosonoic, } \\
\text { Stearic, Arachidic Acid, Urosilic Acid, }\end{array}$ \\
\hline
\end{tabular}




\begin{tabular}{|c|c|c|c|}
\hline & & & $\begin{array}{l}\text { Hentriacontane, Becdysone, Triacontanol. } \\
\text { Punarnavoside (Antifibrinolytic Glycoside, } \\
0.03-0.05 \% \text { ); Oeravinones, Lignans } \\
\text { (Liridodendrin, Boeravine \& Hypoxanthine } \\
\text { Deriv .) ; Flavones, Sterols; Root Contains } \\
\text { Alanine, Arachidic Acid, Aspartic Acid, } \\
\text { Behenic Acid, Boerhavic Acid, } \\
\text { Boerhavone, Pot.Nitrate (6.5\%), Oxalic } \\
\text { Acid, Punarnavine } 1 \text { And } 2 \text { Etc. }\end{array}$ \\
\hline Shatavari & $\begin{array}{l}\text { Asperagus recemosus; } \\
\text { Asparagaceae }\end{array}$ & $\begin{array}{l}\text { Tuberous } \\
\text { Dried Root }\end{array}$ & $\begin{array}{l}\text { Saponins-Shatavarins I-IV. Shatavarin } \\
\text { IV Is A Glycoside Of Sarsasapogenin. } \\
\text { Dried Root Yields Sitosterol; (Dihydroxy- } \\
\text { O Hydroxyisobutyl) Benzaldehyde And } \\
\text { Undecanyl Cetanoate, And Contains A } \\
\text { Large Amount Of Saccharine Matter, } \\
\text { Mucilage And Minerals }\end{array}$ \\
\hline Changal jadi & Coleus forskohlii; Lamiaceae. & Root & Ditermene Coleonol, \\
\hline Ambashthaki & Hibiscus sabdariffa; Malvaceae & Calyxes & $\begin{array}{l}\text { Oxalic,Malic,Citric,Tarteric Andhibiscic } \\
\text { Acid }\end{array}$ \\
\hline Draksha & Vitis vinifera; vitaceae & $\begin{array}{l}\text { Seed } \\
\text { Extract }\end{array}$ & $\begin{array}{l}\text { Grape Skin Produces Endothelium } \\
\text { Dependent Aorta Relaxation Possibly By } \\
\text { Its Flovonoids (Quercetin) }\end{array}$ \\
\hline Olive leaf & $\begin{array}{l}\text { Olea africana and Olea europea; } \\
\text { Oleacae }\end{array}$ & Leaf & $\begin{array}{l}\text { Oleuropein, A Complex Structure Of } \\
\text { Flavonoids, Esters, And Multiple Iridoid } \\
\text { Glycosides,"," }\end{array}$ \\
\hline Lotus & $\begin{array}{l}\text { Nelumbo nucifera; } \\
\text { Nelumbonaceae }\end{array}$ & Arial Parts & $\begin{array}{l}\text { Alkaloids Including Liensinine, } \\
\text { Isoliensinine, Referine, Lotusine, } \\
\text { Methylcorypalline, And } \\
\text { Demethylcoclaurine. Among Them, } \\
\text { Referine Has Been Shown To Have A } \\
\text { Vasodilating Effect And Liensinine Has } \\
\text { Antihypertensive And Antiarrhythmic } \\
\text { Abilities }\end{array}$ \\
\hline
\end{tabular}

\section{Discussion:-}

\section{Probable mode of action of panchkarma-}

\section{Basti ${ }^{[12]}$}

BP is regulated by the feedback of the neural tissue of Vaso-Motor Center (VMC). VMC activity in turn depends upon reflexes from periphery (neural and chemical) and from higher center. Sympathetic stimulation causes activation of pressure area of $\mathrm{VMC}$, which in turn causes vasoconstriction and leads to rise in $\mathrm{BP}$, while parasympathetic stimulation causes activation of depressor area of VMC, which in turn results in vasodilatation and precipitates decrease in BP. The long-term regulation of BP occurs through Renin-Angiotensin-Aldosterone (RAA) axis of endocrine mechanisms. Lower part of GIT is richly supplied with parasympathetic nerves which on stimulation with Basti (either by chemical or mechanical receptor) may cause decrease in secretion of RAA complex, and by activating depressor area of VMC which causes vasodilatation and results in decrease in BP. Enteric Nervous System (ENS) works in synergism with the CNS on stimulation with Basti (either by chemo or mechano receptors) and may lead to activation of depressor area of VMC, which finally causes decrease in BP. It is not mandatory for a drug to remain in contact with the receptor for long time e.g. in proton pump inhibitor mechanism, the drug interacts with receptor and gets flushed out from circulation, it is known as "hit and run module" of kinetics. The same module of kinetics can be hypothesized for Niruha Basti.

Virechan ${ }^{[13]}$

Virechana process can remove excess of sodium ions and excrete potassium through G.I.T. Watery stool cause depletion of bicarbonate. Virechana can eliminate bicarbonate. It can maintain Acid-Base balance too. By the process of Virechana, we may say that Virechana may give effect on Angiotensin-II enzyme, which helps to reduce 
retention of salt and water, which decrease extra-cellular fluid from the body, which ultimately decreased blood pressure.

\section{Shirodhara ${ }^{[13]}$}

Local application as Ointment may pass through the Stratum corneum into blood vessel and producing desirable effects by reaching the target organ. The continuous pouring of Liquid in relaxed and comfortable position has an additional effect which can be compared to cradling of Mother to a child. This function act as a Sedative and Soothing effect for the Brain and produces Sleep. Materials used for Shirodhara is always warm which causes vasodilatation of all the channels and thereby improving their circulation which in turn improves the blood circulation of Brain. This improves the higher intellectual functions also. So an improvement in psychic symptoms is achieved. Improvement in circulation to hypothalamus also improves the function of Autonomic Nervous System as its stimulation during stress causes many physiological disturbances. Shirodhara may also have Alpha Adrenergic blocking effect and can thus block certain actions of adrenaline and nor adrenaline. Shirodhara may also act on the adrenergic neuron probably produce their effects by modifying the synthesis storage and uptake mechanisms of noradrenaline. Regulation of emotional and behavioral patterns: Together with the limbic system with the hypothalamus regulates the feeling of rage, aggression, pain and pleasure and behavioral patterns of sexual arousal Ultimately it can be postulated that Shirodhara may be having some effect on hypothalamus resulting in decrease of most of the psychic and somatic disorders. By affecting in all these ways, Shirodhara gives results in EHT.

\section{Mode of Action of Shaman Drugs ${ }^{[11]}$}

1. Centrally acting- withania (CNS acting), rauwolfia (catcholaminedepeleters), hypericum (dopamine and norepinephrine re-uptake inhibitors), black cumin seed (CNS acting and antioxidant)

2. Vasodilators- Garlic (Via Hyperpolarization through $\mathrm{H}_{2} \mathrm{~S}$ ), Ginseng (Direct Smooth Muscle Relaxant), Hawthorn, Vitis, Yarrow, Olive Leaf (Endothelium Dependent Vasodilation), Forskolin (AdenylCyclase Pathway), Lotus

3. Diuretic - punarnava, kalaaja

4. ACE inhibitors- Garlic (by allicin), vacha, bibhitaki, pippali

5. Calcium channel antagonist- shunthi, brahmi

6. Cholesterol Synthesis Inhibitors- Cat's claw, African mistletoe

7. Hypolipidemic- matulunga, amlavetas, vrikshamla, pushkarmool

\section{Conclusion:-}

Essential hypertension is a deadly disease leading to many cardiovascular, cerebral and renal events. Treatment of this disease is still very challenging and complicated. Ayurveda can offer better treatment modalities. Following good dietary code and conducts and lifestyle modification along with panchakarma shodhan therapies and shaman medicines, nation can cope up with this disease. The ideal prescription for this disease should be "lifestyle prescription".

\section{References:-}

1. Pt. Kashinath sastri and dr. Gorakhnath chaturvedi .vidyotani on charak samhita of charak, sutrasthana, chapter 1, verse no. 15. Varanasi; chaukhambha bharti academy; 2013:07

2. K.chaudhary,parul sharma, ved bhushan sharma. Hypertension and its management through ayurveda. Journal of ayurvedic and holistic medicine 2015;3: 3

3. Wikipedia contributors. Wikipedia, the free encyclopedia. [updated 4 june 2019 23:05 utc cited 25 july 2019 14:08 utc]. Available from https://en.wikipedia.org/w/index.php?title=essential_hypertension\&oldid=900330572 page version id: 900330572

4. Thankappan kr, sivasankaran s, sarma ps, mini g, khader sa, padmanabhan p, et al. Prevalence-correlatesawareness-treatment and control of hypertension in kumarakom, kerala: baseline results of a community-based intervention program. Indian heart j 2006; 58:28-33

5. Gupta r. Meta-analysis of prevalence of hypertension in india. Indian heart j 1997; 49:450

6. Das sk, sanyal k, basu a. Study of urban community survey in india: growing trend of high prevalence of hypertension in a developing country. Int $\mathrm{j}$ med sci $2005 ; 2: 70-78$

7. Pt. Kashinath sastri and dr. Gorakhnath chaturvedi .vidyotani on charak samhita of charak, sutrasthana, chapter 18, verse no. 44. Varanasi; chaukhambha bharti academy; 2013:383 
8. Vaidya yadunandan upadhayaya editor. Ashtanghridyam: sutra sthana chapter13, verse 25, varanasi; chaukhamba prakashana; 8th ed.:111

9. Unknown author, hypertension.ccras. Available from: http://www.ccras.nic.in/sites/default/files/viewpdf/faq/hypertension.pdf

10. Atul kale. A clinical study on the ayurvedic samprapti of essential hypertension and its management with sarpagandhadi vati . Thesis-kayachikitsa ; jamnagar;ipgt\&r;2005:14-16

11. Manish agrawal, d. Nandini, vikas sharma and n. S. Chauhan; "herbal remedies for treatment of hypertension"; international journal of pharmaceutical sciences and research (2010), vol. 1, issue 5:1-21

12. gyanendra shukla, santosh k. Bhatted,alankruta r. Dave, and vageesha datta shukla;" "efficacy of virechana and basti karma with shamana therapy in the management of essential hypertension: a comparative study"; ayu 2013 jan-mar; 34(1): 70-76.

13. Dr chirag gujarati ,dr shital bhagiya ,dr nilesh bhatt, dr devang patel; "anti-hypertensive effect of virechana, basti karma and shirodhara - a review"; ayurpub, march-april 2017; volume2,issue 2; 442-450. 